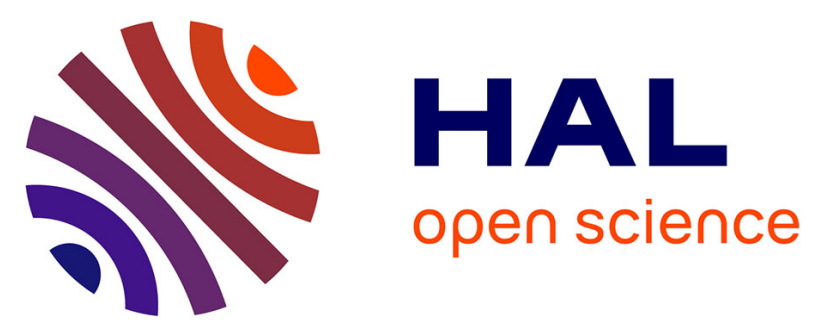

\title{
Experimental evidence for the decline of submerged vegetation in freshwater ecosystems by the invasive Chinese mitten crab (Eriocheir sinensis)
}

Jonas Schoelynck, Jan-Willem Wolters, Johannes Teuchies, Natacha Brion, Sara Puijalon, Dante Horemans, Heleen Keirsebelik, Lieven Bervoets, Ronny Blust, Patrick Meire

\section{To cite this version:}

Jonas Schoelynck, Jan-Willem Wolters, Johannes Teuchies, Natacha Brion, Sara Puijalon, et al.. Experimental evidence for the decline of submerged vegetation in freshwater ecosystems by the invasive Chinese mitten crab (Eriocheir sinensis). Biological Invasions, 2019, 22 (2), pp.627-641. 10.1007/s10530-019-02118-2 . hal-02353652

\section{HAL Id: hal-02353652 \\ https://univ-lyon1.hal.science/hal-02353652}

Submitted on 17 Dec 2020

HAL is a multi-disciplinary open access archive for the deposit and dissemination of scientific research documents, whether they are published or not. The documents may come from teaching and research institutions in France or abroad, or from public or private research centers.
L'archive ouverte pluridisciplinaire HAL, est destinée au dépôt et à la diffusion de documents scientifiques de niveau recherche, publiés ou non, émanant des établissements d'enseignement et de recherche français ou étrangers, des laboratoires publics ou privés. 
Experimental evidence for the decline of submerged vegetation in freshwater ecosystems by the invasive Chinese mitten crab (Eriocheir sinensis)

\section{Authors:}

Schoelynck, Jonas ${ }^{1, *}$

Wolters, Jan-Willem ${ }^{1}$

Teuchies, Johannes ${ }^{2}$

Brion, Natacha ${ }^{3}$

Puijalon, Sara ${ }^{4}$

Horemans, Dante M.L. ${ }^{1}$

Keirsebelik, Heleen ${ }^{1}$

Bervoets, Lieven ${ }^{2}$

Blust, Ronny ${ }^{2}$

Meire, Patrick ${ }^{1}$

${ }^{1}$ University of Antwerp, Department of Biology, Ecosystem Management Research Group, Universiteitsplein 1C, B-2610 Wilrijk, Belgium

${ }^{2}$ University of Antwerp, Department of Biology, Systemic Physiological and Ecotoxicological Research, Groenenborgerlaan 171, B-2020 Antwerp, Belgium

${ }^{3}$ Vrije Universiteit Brussel, Analytical and Environmental Geochemistry, Pleinlaan 2, 1050 Brussels, Belgium

${ }^{4}$ Université Lyon 1, CNRS UMR 5023, Ecologie des Hydrosystèmes Naturels et Anthropisés, F69622 Villeurbanne, France

\section{*Corresponding author:}

Jonas Schoelynck

UA - Campus Drie Eiken

Ecosystem Management Research Group

Universiteitsplein 1

Building C, Room C1.29

B-2610 Wilrijk, Belgium

jonas.schoelynck@uantwerpen.be

Tel +32 32652252

Keywords: Myriophyllum spicatum; mesocosm experiment; invasive species; glyphosate; EDTA; light limitation; plant stress

\section{Acknowledgements}


The authors would like to thank Maria-Rose Eves-down, Rosanne Reitsema, Steven Jacobs, Lennert Schepers, Babette Muyshondt and Ken Schoutens (University of Antwerp) for their help with the preparation of the experiments and processing of the samples, Brecht Peeters and Paul Van Loon (VMM) for the delivery of freshly caught crabs, David Verstraeten (VUB) for his support with the isotope measurements, Freddy Dardenne (University of Antwerp) for technical support in the Mesodrome, Jana Goyens (University of Antwerp) for lending us her Charge Amplifier, and Raewyn Town for proofreading the manuscript. J.S. is a postdoctoral fellow of FWO (project no. $12 \mathrm{H} 8616 \mathrm{~N}$ ). This research was executed with the financial support of the University of Antwerp, BOF KP 2017 (project no. FFB170019). The Mesodrome was financed through the Hercules funding (contract numbers AUHA/11/04 and G0C4212N). 


\section{Abstract}

2 The Chinese mitten crab (Eriocheir sinensis) is a damaging invader which is designated as a 3 species of Union Concern within the European Union. A negative impact of the crabs on

4 macrophyte vegetation in lowland rivers is suspected but not yet proven or quantified. We have

5 performed a mesocosm study that combines a density gradient of Chinese mitten crabs $(0,0.3,1.0$

6 and 2.5 ind. $\left.\mathrm{m}^{-2}\right)$ with chemical stress $\left(2350 \mu \mathrm{g}\right.$ EDTA $\mathrm{L}^{-1}+258 \mu \mathrm{g}$ glyphosate $\left.\mathrm{L}^{-1}\right)$ or light

7 limitation stress (-70\% irradiance compared to control) on water plants (Myriophyllum spicatum).

8 The results clearly demonstrate that the crabs are capable of removing plant shoots effectively

9 which can lead to a complete elimination of the vegetation. Generally, the higher the crab density,

10 the sooner the plants started to disappear and the sooner the vegetation was completely removed.

11 Additional light and chemical stress accelerated this process: plant disappearance at a crab density

12 of 0.3 ind. $\mathrm{m}^{-2}$ compared to 1.0 ind. $\mathrm{m}^{-2}$ in the control treatments. Video recording, plant strength

13 and crab pinch strength measurements and stable isotope signatures of $\delta^{13} \mathrm{C}$ and $\delta^{15} \mathrm{~N}$ in the

14 Chinese mitten crabs and their possible food sources showed that directly eating the plants is

15 causing only minor damage to the plants. Most damage comes from the movement of the crabs

16 and crab-crab interactions during which they use their chelae to grasp the shoots. We conclude that

17 a decline of vegetation as a consequence of Chinese mitten crab behaviour can be a realistic

18 scenario in freshwater ecosystems and warrants close attention and monitoring. Being primary

19 producers and ecosystems engineers, macrophytes are key species in these ecosystems, whose

20 services are lost when they disappear and are difficult to restore.

\section{Introduction}


23 Invasive alien species (IAS) are major drivers for the loss of biodiversity and associated ecosystem

24 services. The economic costs of these invasions, in Europe alone, are estimated to be 12 billion

25 euro each year, with a strong likelihood to increase in the coming years (European Environment

26 Agency (EEA) 2012). Not surprisingly, applied ecological research on IAS populations is

27 considered as one of the most urgent nature conservation issues by the EEA. Member states are

28 obliged to take measures to eradicate these species. The Chinese mitten crab (Eriocheir sinensis

29 H. Milne-Edwards (Decapoda: Varunidae)) is one of the 49 species listed in EU Regulations (EU

30 Regulation No 1143/2014). Since the first observation of the Chinese mitten crab in the German

31 River Aller in 1912, this IAS has spread rapidly throughout many parts of Europe.

33 In vegetated lowland streams and rivers, aquatic plants provide many ecosystem services (e.g.

34 O'Hare et al. 2018). They play a major role in the evaluation criteria of the European Water

35 Framework Directive (WFD) and/or nature conservation programs (e.g. Natura 2000 goals). Since

36 the summer of 2013, a nearly total absence of macrophytes is observed in a large part of the Grote

37 Nete river in Belgium, where previously plant growth was abundant. Chinese mitten crabs were

38 observed in the Nete catchment, but not exclusively in the section where the macrophytes were

39 lost (VMM 2015; VMM 2017). These studies however, do not mention crab densities, which may

40 have varied in different parts of the catchment. Chinese mitten crabs are omnivorous and

41 opportunistic and feed on almost any organic food source they can find, including living

42 macrophytes (Jin et al. 2001, 2003; Mao et al. 2016). Crayfish in general can threaten the

43 development of submerged macrophytes (van der Wal et al. 2013). This may pose a threat to the

44 resident flora and fauna and may lead to loss of biodiversity (Rogers 2000; Wójcik et al. 2015).

45 Burrowing activities also often make river beds and banks more susceptible to erosion which can 
46 induce resuspension of sediment, increase in turbidity and decrease in light availability (Bouma

47 and Soes 2010; Jin et al. 2003; Wang et al. 2017). These effects increase the vulnerability of plants

48 to uprooting, which may subsequently influence the release of nutrients and pollutants from the

49 sediment (Wang et al. 2017). It has also been shown that macrophytes can be more susceptible to

50 herbivory when they are already under stress (Hidding et al. 2016; Wang et al. 2017). The

51 combination of increased environmental stress and an increased crab population in lowland rivers

52 may thus pose a threat to aquatic flora (which could be the case in the aforementioned section of

53 the Grote Nete river).

55 Increased concentrations of ethylenediaminetetraacetic acid (EDTA) and glyphosate were also

56 often found throughout the Nete catchment, especially near the effluent of waste water treatment

57 plants (VMM 2015; VMM 2017). EDTA is a chelating agent that forms very stable complexes

58 with essential metal ions (e.g. Fe) and major cations such as $\mathrm{Ca}^{2+}$ and $\mathrm{Mg}^{2+}$, which can result in

59 limited uptake and ensuing deficiency of these elements in macrophytes (Hangarter and

60 Stasinopoulos 1991). Glyphosate (N-(phosphonomethyl)glycine) is the active compound of

61 various commercially available herbicides. It inhibits an enzyme in plants (5-

62 Enylpyruvylshikimate-3-phosphate synthase, EPSPS) which is a key step in making aromatic

63 amino acids, thereby preventing the synthesis of metabolites, including flavonoids, lignins and

64 other phenolic compounds (Dill 2005). Insufficient phytotoxic evidence however, was found to 65 point to the right cause of macrophyte loss in the Grote Nete river (VMM 2015). 
67 The objective of this study is to investigate whether the activities of invasive Chinese mitten crabs

68 (herbivory and cutting) can cause a decline of native mature aquatic vegetation. To achieve this

69 objective, a mesocosm experiment was conducted in which the decline of vegetation patches was

70 followed under different crab densities, and in combination with different types of abiotic stress

71 factors on the vegetation. The abiotic stress factors (chemical stress and light limitation stress)

72 were inspired by the case study described above (Grote Nete river), and the following hypotheses

73 are put forward: (i) beyond a certain crab density threshold, macrophyte shoots are negatively

74 affected by crab activity such as consuming or cutting plants; (ii) this can result in a decimation of

75 the entire vegetation patch and a hampered regrowth from its root system; and (iii) abiotic stressors

76 on plants (e.g. chemical and light limitation stress) can influence the level of damage caused by

77 crab activity.

79 Material and Methods

80 Experimental setup

81 The experiment took place in 12 circular mesocosm tanks ( $2 \mathrm{~m}$ diameter). These tanks (ponds) are

82 located in a greenhouse of the Mesodrome research facility at the University of Antwerp. The

83 greenhouse is a semi-controlled environment in a sense that daylight (length and intensity) and

84 temperature are natural, but other influences such as precipitation, wind etc. are controlled. The

85 experiment was conducted between April and June 2017, which is during the growth period of the

86 vegetation and during the anadromous migration of the juvenile crabs used in the experiment.

87

88 A layer of $5 \mathrm{~cm}$ coarse $(0-2 \mathrm{~mm})$ commercially bought river sand was added to each tank. Tap 89 water was added to create a water depth of $0.5 \mathrm{~m}$ (sand bulk density $=1.97 \mathrm{~g}$ dry weight $(\mathrm{DW}) \mathrm{cm}^{-}$ 
$90{ }^{3}$; sand: water volume ratio $=0.1$ ). Water quality parameters $\mathrm{PO}_{4}{ }^{3-}, \mathrm{TDIN}, \mathrm{pH}$, electric conductivity

91 (EC) and dissolved oxygen were measured at the beginning of the experiment and subsequently

92 monitored once per month (Table 1). A colorimetric segmented flow analyser was used for nutrient

93 analysis (SAN++, Skalar, Breda, The Netherlands) and a WTW Multi 3430 SET F multimeter

94 (Weilheim, Germany) for $\mathrm{pH}, \mathrm{EC}$ and $\mathrm{O}_{2}$ measurements. Water temperature was logged

95 continuously with an iButton Hygrochron Temperature/Humidity Data Logger (Maxim Integrated

96 Products, Sunnyvale, CA, USA). Light irradiance above the water surface was logged

97 continuously with Hobo data loggers (Onset, S-LIA-M003, PAR Sensor). In the middle of each

98 tank, a plastic tray was placed $(33 \times 41 \times 10 \mathrm{~cm})$. This tray was filled with the same sand as in the

99 rest of the tank. The top was sealed with a mesh wire with a mesh size of $25 \mathrm{~mm}$ so that crabs

100 could not fully dig into the sand to avoid uprooting, though their legs and chelae could still access

101 the root system to a certain extent. In each tray 150 shoots of commercially bought Myriophyllum

102 spicatum L. (Haloragaceae) were planted, with a combined weight of $90.0 \pm 15.9 \mathrm{~g}$ fresh weight

103 (FW) $(7.5 \pm 1.3 \mathrm{~g} \mathrm{DW})$. Furthermore, ceramic flower pots were added as a shelter for the crabs

104 (one pot for each crab to avoid competition), and an air stone was installed to aerate the tanks.

105 Finally, leaf litter consisting of 5 common tree species, Quercus robur L. (Fagaceae), Q. rubra L.,

106 Fagus sylvatica L. (Fagaceae), Castanea sativa Mill (Fagaceae) and Populus $\times$ canadensis Moench

107 (Salicaceae), was added to provide an alternative food source for the crabs. Tree leaves were oven-

108 dried for $72 \mathrm{~h}$ at $70{ }^{\circ} \mathrm{C}$ and then pre-conditioned for 1 week in pond water. The leaves were divided

109 over 12 plastic trays $(18 \times 33 \times 10 \mathrm{~cm})$ and brought into the 12 tanks $(650 \mathrm{~g} \mathrm{FW}(163 \mathrm{~g} \mathrm{DW})$ per

110 mesocosm). The trays were covered with a mesh wire (mesh size $25 \mathrm{~mm}$ ) to keep the leaves in the

111 trays and avoid floatation. Two holes of $5 \times 5 \mathrm{~cm}$ allowed the crabs to easily access the tray. Plants 
112 were allowed to acclimatise, root and grow in optimal conditions for 3 weeks before chemical and

113 light limitation stress were imposed (Fig. 1).

114

115 Chemical stress was introduced by adding EDTA and glyphosate together to the first four tanks.

116 EDTA was added as $\mathrm{Na}_{2} \mathrm{H}_{2}$ EDTA. $2 \mathrm{H}_{2} \mathrm{O}$ at a concentration of $2350 \pm 58 \mu \mathrm{g} \mathrm{L}^{-1}$ measured five

117 weeks after introduction (not filtered; Gas Chromatography, ISO standard 16588). Glyphosate was

118 added as Roundup® which had a glyphosate concentration of $258 \pm 27 \mu \mathrm{g} \mathrm{L}^{-1}$ measured five weeks

119 after introduction (not filtered; Gas Chromatography, ISO standard 16588). Note that the added

120 concentration of both chemicals at the beginning was higher $\left(5000 \mu \mathrm{g}\right.$ EDTA L ${ }^{-1}$ and $500 \mu \mathrm{g}$

121 glyphosate $\mathrm{L}^{-1}$ ) since a certain fraction will degrade or can adsorb to surfaces (plastic of the

122 containers, sand grains, organic matter etc.) and become inactive. The resulting measured

123 concentrations are high, but are in the same order of magnitude of values found in the Grote Nete

124 catchment, i.e. $2150 \mu \mathrm{g}$ EDTA L $^{-1}$ found in effluent of the wastewater treatment plant discharging

125 into the Grote Nete river and up to $140 \mu \mathrm{g}$ glyphosate $\mathrm{L}^{-1}$ found in waterways in Flanders

126 (monitoring data Flemish Environment Agency, VMM)).

127

128 Light limitation stress was introduced as a $\sim 70 \%$ light reduction to a second series of four tanks 129 by covering the tanks with layers of a white, plastic shade cloth. The imposed light reduction was 130 based on experiments by Barko and Smart (1981) and Zefferman (2004) in which the effect of 131 different shading intensities on $M$. spicatum were tested. They demonstrated that a $70 \%$ light 132 reduction resulted in similar shoot numbers and shoot lengths as in the control treatment (Barko 133 and Smart 1981), and a limited reduced biomass and relative growth rate compared to the full light 134 level (Zefferman 2004). Therefore, a $70 \%$ reduction can be considered to be stressful for the plants, 
135 without impeding their growth. A small test prior to the experiment in which a comparable range

136 of light reduction was used, showed similar results as the Barko and Smart (1981) and Zefferman

137 (2004) experiments (unpublished data).

139 The remaining four tanks are the control treatments. One week after the addition of the light 140 limitation and chemical stress, most of the shoots had reached the water surface and started to 141 produce flowers which indicated they had become mature plants. At this moment, crabs were 142 added to the tanks (Fig. 1). Crabs were preselected based on their condition (visual appearance of 143 good health based on mobility, colour, and presence of all limbs) and similarity in size and weight $144(21.9 \pm 2.1 \mathrm{~g} \mathrm{FW})$. No gender selection was made. For each stress treatment and control, 1 tank 145 received no crabs (reference within each treatment), 1 tank received 1 crab, 1 tank received 3 crabs 146 and 1 tank received 8 crabs. This corresponds to crab densities of 0 ind. $\mathrm{m}^{-2}, 0.3$ ind. $\mathrm{m}^{-2}, 1.0$ ind. $147 \mathrm{~m}^{-2}$ and 2.5 ind. $\mathrm{m}^{-2}$, respectively. Because related omnivorous Sesarmid crabs are known to 148 supplement their diet with animal tissue such as fish carcasses, to provide a major part of their 149 dietary nitrogen requirements, crabs were offered fish meat weekly ( $\pm 1 \mathrm{~g}$ anchovies per crab) to 150 ensure a balanced diet and to avoid cannibalism (Thongtham and Kristensten 2005; Kristensen et 151 al. 2010). Each two to five days, plant shoots that were cut by the crabs and floated in the tanks 152 were retrieved, oven-dried at $70^{\circ} \mathrm{C}$ for at least $48 \mathrm{~h}$ and weighed. The experiment lasted for 25 153 days because at this time most of the vegetation in the stressed treatments with the highest crab 154 density was gone.

155 After the experiment, the crabs were retrieved and weighed again, then stored frozen at $-20{ }^{\circ} \mathrm{C}$ 156 until further analysis. The remaining plant biomass in the trays was cut by hand just above the 157 mesh wire, oven-dried at $70{ }^{\circ} \mathrm{C}$ for at least $48 \mathrm{~h}$ and weighed. The sum of the remaining plant 
158 biomass and the floating plant biomass collected during the experiment gives the total plant 159 biomass. All 12 trays were then together transferred to a tank with fresh tap water and in optimal conditions. The water quality was the same as at the start of the previous experiment (Table 1) and

161 was not monitored further. Regrowth of the shoots was visually evaluated weekly during 7 weeks

162 (short term period) after which the biomass was determined again by cutting all shoots just above

163 the mesh wire, drying and weighing. The presence of flowers was noted. The trays were then 164 placed back into the tank for a new, long term period of regrowth. After 1 year, all biomass was 165 determined again by cutting all shoots just above the mesh wire, drying and weighing. The 166 presence of flowers was again noted.

Plant nutrient concentrations

169 To compare the nutrient condition of the plants between the treatments, total phosphorus content 170 of plants from all 12 tanks was determined at the end of the experiment according to Walinga et

171 al. (1989): samples were digested with $\mathrm{H}_{2} \mathrm{SO}_{4}, \mathrm{HOC}_{6} \mathrm{H}_{4} \mathrm{COOH}$ and $\mathrm{H}_{2} \mathrm{O}_{2}$ and analysed on a 172 colorimetric segmented flow analyser (SAN++, Skalar, Breda, The Netherlands). Total carbon and 173 nitrogen content of plants from all 12 tanks was determined during the procedure for stable isotope 174 analysis (see below).

176 Crab pinch test

177 To compare the force of the crabs with the resisting strength of the plants, crab pinch strength of 17840 individuals of each sex and of different body mass was measured using a Charge Amplifier 179 (Kistler Instrumente AG, Type 5995, Winterthur, Switserland). The crabs were preselected based 180 on their condition (visual appearance of good health). Five pinches were measured for each crab, 
181 using 1 chela at the time, and randomly alternating between chelae. Maximum pinch strength (out

182 of 5) and average pinch strength $(n=5)$ are plotted against the crab biomass ( $\mathrm{g} \mathrm{FW})$.

184 Plant shear test

185 Shearing tests were used to measure the stem resistance to fracture. For each treatment, the test 186 was undertaken on 5 stems. Tests were conducted with a leaf-cutting device following Ang et al. 187 (2008), mounted on a universal testing machine (Instron 5942, Canton, MA, USA). A single 188 stainless-steel blade of a straight razor (Dovo, Solinge, Germany) was mounted on the moving 189 head of the testing machine with an approach angle of $20^{\circ}$. The stem was positioned on 2 supports 190 (with a $15 \mathrm{~mm}$ span), with the blade being equidistant from the 2 supports. The blade was moved 191 downward at a constant speed of $10 \mathrm{~mm} \mathrm{~s}^{-1}$ shearing the stem into 2 parts. The maximum load 192 applied to the leaf $(\mathrm{N})$ was recorded with a frequency of $10 \mathrm{~Hz}$ and used to calculate the maximum 193 force to shear the stem $(\mathrm{N})$ and the shear strength (maximum force divided by the cross-sectional 194 area, MPa). To take into account the high proportion of lacunae in stems of aquatic plants, the 195 cross-sectional area used to calculate shear strength was the effective cross sectional area, 196 calculated as the difference between total cross-sectional area and total lacuna area. This correction 197 is used to quantify the effective cross-sectional area supporting forces in the shearing tests. To 198 measure cross-sectional area of the stem sheared, thin cuts adjacent to the shearing plane were 199 made. Images of the cuts were taken using a binocular and a digital camera and analysed with 200 Leica Application Suite (v4.3, Leica Microsystems, Switzerland) to calculate total stem cross201 sectional area $\left(\mathrm{mm}^{2}\right)$ and total lacuna area $\left(\mathrm{mm}^{2}\right)$. 
204 To calculate the relative importance of the food sources, stable isotope signatures $\left(\delta^{13} \mathrm{C}\right.$ and $\left.\delta^{15} \mathrm{~N}\right)$

205 were measured for all different 'food web' components in the mesocosms; the crabs as consumers

206 and M. spicatum, leaf litter and supplementary fish as food sources. Crabs were dissected to collect

207 their gill tissue, which was subsequently freeze dried using a Heto PowerDry LL3000 (Thermo

208 Scientific) and ground using a Retsch mixer mill (MM301). Only gill tissue was extracted for

209 isotope analysis, due to its low turnover rate compared to other tissues (Lorrain et al. 2002). Dried

210 M. spicatum shoots and leaf litter were ground with a Retsch ZM200 ultra-centrifugal mill.

211 Powdered samples were weighed in silver cups and acidified with one drop of 5\% hydrochloric 212 acid, to remove any carbonates (Jacob et al. 2005), and oven-dried at $80^{\circ} \mathrm{C}$ for $4 \mathrm{~h}$ after which the 213 cups were folded and analysed. Sample weights were $5 \mathrm{mg}$ for leaf litter and macrophytes, and 1 $214 \mathrm{mg}$ for crab tissue. Carbon and nitrogen contents were measured using a Flash EA 1112 Elemental 215 Analyzer (Thermo Finnigan). The ${ }^{13} \mathrm{C}$ and ${ }^{15} \mathrm{~N}$ stable isotope signatures were measured using a 216 Delta V Advantage isotope ratio mass spectrometer (Thermo Finnigan) that was coupled, via a 217 ConFlo III interface (Thermo Finnigan), to the Elemental Analyzer.

219 Video recording

220 Two crabs similar to ones used in the experiment, and a patch of 15 mature M. spicatum shoots 221 were placed in a $100 \mathrm{~L}$ aquarium. Crab movements were observed with a camera (Sony CX550) 222 during 3 consecutive $12 \mathrm{~h}$ day and $12 \mathrm{~h}$ night cycles (using the infra-red mode of the camera). The 223 aim was to record the interaction of the crabs with the plants in a qualitative way to observe 224 whether crabs climb into the patch, if they use their chelae to grasp the shoots and whether they 225 cut the shoots directly. 
228 First, the impacts of the different treatments and crab densities on plant biomass is compared. An 229 empirical model for the fraction of biomass remaining (FBR) as a function of time $(t)$ is proposed:

231 Fraction of Biomass Remaining $=\frac{1}{1+e^{-\delta[\tau-t]}}$

233 The FBR-model (Eq. 1) computes the fraction of biomass remaining after a time $t$ of running the

234 experiment. At time $t=0 \mathrm{~s}$, the FBR equals one. When the experiment duration $t$ approaches $\tau$ 235 [units s], the FBR starts to decay at an exponential decay rate $\delta$ [units s${ }^{-1}$ ]. For $t$ significantly larger 236 than $\tau$ the FBR converges to zero. The larger is $\tau$, the longer it takes for the system to start 237 declining. Every dataset for FBR as a function of time from each mesocosm tank will have its own 238 set of parameters $\tau$ and $\delta$. The parameters are obtained by fitting the dataset to the model. By doing 239 so the different stress impacts and crab densities can be compared using the corresponding 240 parameters $\tau$ and $\delta$. More detailed information, and every fit output is given in online 241 supplementary material. All tests were performed in R 3.3.2 (R Development Core Team 2016).

243 Secondly, differences in crab fresh weight before and after the experiment and between stress 244 treatments were tested. Mesocosm tanks with different crab densities but the same stress treatment 245 were used as 4 replicas. Data were first checked for normality distribution via Shapiro-Wilk tests 246 and visual inspection of Q-Q plots. Not normally distributed data were tested for significant 247 differences among groups using Kruskal-Wallis tests and Dunn's post hoc tests. Normally 248 distributed data were checked for equality of error variances using Levene's tests. Significant 249 differences among groups were assessed using one-way ANOVAs with Tukey post-hoc tests for 
250 equal variances or Welch tests and Games-Howell post-hoc tests for non-equal variances.

251 Interaction could not be tested because of the experimental design, though this is not expected to

252 happen and if it occurs it is included in the residual variation of the applied test. Additionally,

253 differences in crab pinch strength between sexes was tested following the same statistical

254 procedure as described above. Relationships between crab pinch strength and crab biomass were

255 defined using Pearson correlation coefficients and tested for significance using two-tailed t-tests.

256 All tests were performed in R 3.3.2 (R Development Core Team 2016).

258 Thirdly, mesocosm tanks with different stress treatments but with the same crab density were used

259 as 3 replicates to test the effect of crab density on plant biomass. Mesocosm tanks with different

260 crab densities but the same stress treatment were used as 4 replicas to test for differences in plant

261 nutrient concentrations, plant shear force, and total plant biomass between different stress

262 treatments. The same statistical procedure was used as described above for testing differences in

263 crab characteristics.

265 Finally, stable isotope data was used to calculate the relative importance of the food sources in the

266 crab's diet. The stable isotope mixing model 'Stable Isotope Analysis in R' (SIAR, Parnell and

267 Jackson 2013) package (version 4.2) was used under 3.3.2 (R Development Core Team 2016) for

268 this purpose. This Bayesian mixing model incorporates variation in the stable isotope $\left(\delta^{13} \mathrm{C}\right.$ and

$269 \delta^{15} \mathrm{~N}$ ) signatures of the different food sources and the consumer and subsequently calculates

270 density plots of credible intervals for the estimated dietary proportion of each food source (Parnell

271 et al. 2010; Parnell and Jackson 2013). Furthermore, this mixing model allows the incorporation

272 of food source $\mathrm{C}$ and $\mathrm{N}$ content, thereby enabling better resolution when analysing food sources

273 with vastly different $\mathrm{C}$ and $\mathrm{N}$ concentrations (Phillips and Koch 2002), e.g. for omnivores that may 
274 consume both nitrogen poor detritus and nitrogen rich animal material. Before incorporation in the

275 model, the food source carbon and nitrogen stable isotope signatures were corrected for trophic

276 fractionation by adding $0.8 \%$ and $2.6 \%$ respectively, for animals of which only muscle tissue was

277 analysed (McCutchan et al. 2003).

278

279 Results

280 Impacts of the different stress treatments and crab densities on plant biomass

281 The results clearly demonstrate that the crabs were able to remove plant shoots effectively, leading 282 to a complete elimination of the plant patch (Fig. 2). If no crabs were present (reference tanks), no 283 shoots were cut. When crabs are present, many shoots were cut and the amount and timing was 284 influenced by crab density and additional stress treatment. The fraction of biomass remaining as a 285 function of time follows a sigmoid pattern (see Fig. S1-S3 in online supplementary material). For 286 all experiments (light limitation- and chemical stress, and the control treatment), the threshold 287 value $(\tau)$ exponentially decreased as a function of crab density with an exponential coefficient $\alpha_{\text {light }}$ 288 and $\alpha_{\text {chemical }}$ and $\alpha_{\text {control }}$ respectively (see Fig. S5, S7, S9 in online supplementary material). So, the 289 more crabs, the sooner the system will start declining: e.g., having 0.3 ind. $\mathrm{m}^{-2}$ in the control 290 treatment (Fig. 2A), most biomass was still present by the end of the experiment (reduction of only $2915 \%$ ), whereas an increasing crab density in the control treatment led to a removal of all biomass 292 by the end of the experiment (reduction of 100\%), which occurred sooner at the highest crab 293 density (at day 25 for 1.0 ind. $\mathrm{m}^{-2}$ and at day 12 for 2.5 ind. $\mathrm{m}^{-2}$ ). No significant correlation between 294 the rate of collapse $(\delta)$ and crab density was observed once the threshold was reached. When 295 compared to the control experiment, there was a significant $\left(\alpha_{\text {control }}=[0.82 \pm 0.11]\right.$ ind.$^{-1} ; \alpha_{\text {light }}=$ $296[2.30 \pm 1.29]$ ind..$^{-1} ; \alpha_{\text {chemical }}=[1.70 \pm 0.55]$ ind..$\left.^{-1}\right)$ impact of light limitation stress and chemical 
297 stress on the exponential decrease of $(\tau)$ as a function of crab density. In other words, when

298 compared to the control treatment, the start of vegetation decline will be sooner in case of light

299 limitation stress or chemical stress for the same crab density (Fig. 2B, C). No significant difference

300 was observed between the impact of light and chemical stress on macrophyte biomass

301 development.

302

303 Crab characteristics

304 Crab mortality during the experiment was low. Only 3 crabs were found dead in the first few days 305 of the experiment and were immediately replaced by a similar individual. The fresh weight of the 306 crabs at the end of the experiment had increased significantly from $21.9 \pm 6.5 \mathrm{~g}$ to $33.6 \pm 10.7 \mathrm{~g}$ 307 FW during the experiment of 25 days (Kruskal-Wallis test; $\mathrm{X}_{\mathrm{df}=1}^{2}=29.2 ; \mathrm{p}<0.001$ ). Male crabs 308 had a significantly higher average and maximum pinch strength than females, proportional to their 309 body mass (Welch test, maximum strength; $F_{d f=1,59}=19.5 ; \mathrm{p}<0.001$, Average strength; $F_{\mathrm{df}=1,61}=$ $31018.6 ; \mathrm{p}<0.001)$. Additionally, both pinch strengths showed a significant positive relationship with 311 body mass for both male and female crabs (Fig. 3).

313 Plant characteristics

314 Visually, the plants in each of the mesocosms appeared healthy at the end of the initial growth 315 period. They filled the entire water column, produced flowers and had no signs of necrosis or other 316 visual symptoms of aberrant growth. Physiologically, plants grown under light limitation stress 317 had significantly higher concentrations of $\mathrm{N}\left(29.8 \pm 2.4 \mathrm{mg} \mathrm{N} \mathrm{g} \mathrm{DW}^{-1}\right.$ (mean $\pm \mathrm{SD}$ ), one-way 318 ANOVA; $\left.\mathrm{n}=4 ; \mathrm{F}_{\mathrm{df}=2,9}=21.8 ; \mathrm{p}<0.01\right)$ and $\mathrm{P}\left(2.4 \pm 0.4 \mathrm{mg} \mathrm{P} \mathrm{g} \mathrm{DW}{ }^{-1}\right.$, one-way ANOVA; $\mathrm{n}=4$; $\left.319 \mathrm{~F}_{\mathrm{df}=2,9}=15.2 ; \mathrm{p}=0.01\right)$ than the plants from the control $\left(15.7 \pm 3.5 \mathrm{mg} \mathrm{N} \mathrm{g} \mathrm{DW}^{-1}\right.$ and $1.1 \pm 0.1 \mathrm{mg}$ 
$\left.320 \mathrm{P} \mathrm{g} \mathrm{DW}^{-1} ; \mathrm{n}=4\right)$ and chemical treatment $\left(17.4 \pm 5.2 \mathrm{mg} \mathrm{N} \mathrm{g} \mathrm{DW}^{-1}\right.$ and $1.4 \pm 0.3 \mathrm{mg} \mathrm{P} \mathrm{DW}^{-1} ; \mathrm{n}$

$321=4)$. Because carbon content did not vary significantly among the treatments, the C:N and C:P 322 ratios of plants grown under light limitation stress $(\mathrm{C}: \mathrm{N}=12.7 \pm 0.2, \mathrm{C}: \mathrm{P}=136.2 \pm 9.3)$ were 323 consequently lower than in the control $(\mathrm{C}: \mathrm{N}=19.3 \pm 1.5, \mathrm{C}: \mathrm{P}=287.5 \pm 27.3)$ and chemical 324 treatment $(\mathrm{C}: \mathrm{N}=16.6 \pm 2.2, \mathrm{C}: \mathrm{P}=210.2 \pm 17.0)$, although these differences were not significant. 325 Plants grown under light limitation stress also had a significantly lower shear strength $(0.17 \pm 0.03$ $326 \mathrm{MPa})$ than the ones from the chemical treatment $\left(0.26 \pm 0.02 \mathrm{MPa}\right.$, one-way ANOVA; $\mathrm{F}_{\mathrm{df}=2,12=}$ $3274.3 ; \mathrm{p}=0.039)$. The maximum force to shear the stems of the control plants $(0.66 \pm 0.14 \mathrm{~N})$ was 328 significantly higher than from plants from the light treatment $(0.40 \pm 0.1 \mathrm{~N}$, Kruskal-Wallis test; $\left.329 \quad \mathrm{X}_{\mathrm{df}=2}^{2}=5.9 ; \mathrm{p}=0.049\right)$.

331 Total plant biomass (see methods) recovered from the reference tanks at the end of the end of the 332 experiment varied between 23.0 - $33.6 \mathrm{~g} \mathrm{DW}$, depending on the abiotic stressor: control > chemical 333 stress > light limitation stress (Fig. 4). Treatment type therefore did have a significant effect on 334 total plant biomass (one-way ANOVA; $\mathrm{F}_{\mathrm{df}=2,9}=4.62 ; \mathrm{p}=0.042$ ), with light limited plants having 335 a significantly lower biomass than plants from the control treatment $(p=0.038)$. Within each 336 treatment, total plant biomass was not significantly affected by crab density (one-way ANOVA; $337 \quad \mathrm{~F}_{\mathrm{df}=3,8}=1.46 ; \mathrm{p}=0.30$ ). Nevertheless, large variations in total plant biomass between crab density 338 treatments exists, e.g. more than $50 \%$ less biomass if 2.5 ind. $\mathrm{m}^{-2}$ are present compared to the 339 reference situation (Fig. 4).

340

341 Reconstructing crab diet 
342 Clear differences in $\delta^{13} \mathrm{C}$ and $\delta^{15} \mathrm{~N}$ signatures could be observed between the crabs and the three

343 measured possible food sources (Fig. 5). In Fig. 5 the crabs are positioned at the upper left part of

344 the biplot, being relatively depleted in ${ }^{13} \mathrm{C}$, but with high $\delta^{15} \mathrm{~N}$ signatures. Terrestrial leaves were

345 the most depleted in ${ }^{15} \mathrm{~N}$, followed by M. spicatum with slightly higher values and by supplemented

346 fish which was the most enriched in ${ }^{15} \mathrm{~N}$. Terrestrial leaves were the most depleted in ${ }^{13} \mathrm{C}$ in

347 comparison to M. spicatum and fish, which both had comparable $\delta^{13} \mathrm{C}$ signatures.

349 Mixing model calculations showed that most of the crabs' diet consisted of terrestrial leaves and

350 fish meat, with a variable but smaller proportion consisting of M. spicatum (Table 2). The $5^{\text {th }}$

351 percentile value of $M$. spicatum was always 0 , indicating that the chance of $M$. spicatum not being

352 consumed was at least 5\% (Table 2). The only treatments in which $M$. spicatum constitutes a 353 potential important food source (i.e. have a potential maximum contribution higher than 50\%),

354 also had the highest uncertainty due to the low number of crabs being measured, inherent to the 355 crab density imposed. Differences in potential food sources between treatments and crab densities 356 were not consistent.

Regrowth experiment

359 On day 16 of the regrowth experiment, the first shoots reappeared in the patches which came 360 originally from the reference tanks (i.e. with no crabs). On day 47 (short term period), flowers 361 appeared again in the new-grown patches and all shoots were cut at that day. Biomass mainly grew 362 back in the patches that came originally from the reference tanks (Table 3), and one shoot grew 363 back in the tray that used to stay in the tank with the chemical treatment and with the highest crab 364 density. No plant regrowth was observed in any other trays (Table 3). After one year of regrowth 
365 (long term period), the biomass of the patches that came originally from the reference tanks all had 366 flowers and biomass was similar to the biomass in the previous year (Table 3, Fig. 4). All other 367 trays only had a few shoots that grew back and not even all of them managed to produce flowers 368 (Table 3).

370 Discussion

371 This study has shown that the Chinese mitten crabs can negatively impact freshwater flora. One $372 \mathrm{crab}\left(0.3\right.$ ind. $\left.\mathrm{m}^{-2}\right)$, in combination with light limitation or chemical stress, resulted in complete 373 eradication of the experimental vegetation patch in less than 25 days. Within the constraints of our 374 experiment, this crab density could be considered as a threshold value above which vegetation is 375 likely to be impacted by the crabs in presence of other stress factors. The value is similar to the 376 density threshold of $0.25-0.5$ ind. $\mathrm{m}^{-2}$ established by Jin et al. (2001) for macrophytes in the 377 crabs' home territory in China. In all our experiments with 1.0 and 2.5 ind. $\mathrm{m}^{-2}$, vegetation was 378 severely diminished or completely gone within 25 days. However, since this is not a field study, 379 the parameters presented here do not account for the many in situ variables which could mitigate 380 or exacerbate the impact, including: the daily movements and seasonal migration of the crabs, 381 presence or absence of other food sources, combination and intensity of additional biotic and 382 abiotic plant (and crab) stress factors, and the ratio of plant coverage to crab density.

384 Locally and during certain periods of time (e.g. during migrations), it cannot be excluded that crab 385 densities exceed the threshold value in the river resulting in the complete disappearance of aquatic 386 vegetation. This is especially likely when the plants are already stressed by other factors (Hidding 387 et al. 2016; Wang et al. 2017) and other food supplies are restricted. In a natural river, contrary to 
our experimental conditions, several vegetation patches are present over a much larger area and

389 crabs are free to move around. Such conditions probably gives patches time to recover rather than

390 being continuously exposed to the same crab density (which was the case in our experiment).

391 Exposure time is also dependent on vegetation coverage which may be higher in low-order streams

392 (hence a higher threshold value for a given crab density) and lower in high-order streams (hence a

393 lower threshold value for a similar crab density). In the case of our experiment, the above-

394 mentioned threshold value of 0.3 ind. $\mathrm{m}^{-2}$ could be recalculated to the density of crabs per vegetated

395 surface area, instead of per total surface area of the tank, which increases it to 7.4 ind. $\mathrm{m}^{-2}$

396 vegetation. This reasoning corroborates the conclusion of Wang et al. (2017) that plant resilience

397 to disturbance from crabs is reduced in continuous presence of high crab densities. In order to

398 estimate the risk for the vegetation it is advised to report crab density values in relation to the

399 vegetation cover. Note that our experiment was executed with only 1 size class of crabs, and the

400 threshold values observed will probably no longer hold when considering smaller (younger) or

401 larger (older) crabs.

402

403 The regrowth experiment demonstrated that following removal by the crabs, plants were hindered 404 in their ability to grow back in the short and long term, even after their optimal (a)biotic conditions 405 were restored. This may point to a hysteresis effect in the critical crab density that removes 406 vegetation and the critical crab density that allows recovery. The mesh wire prevented the crabs 407 from burrowing into the sediment, but it is likely that their chelae and/or legs were able to reach 408 and damage the root system, thereby inhibiting regrowth. Long-term experiments such as those 409 presented herein are needed to simulate river restoration projects in which crab densities are 410 reduced. A (semi) permanent reduction or even total loss of vegetation can have dramatic 
411 consequences for the aquatic ecosystem since macrophytes are ecological engineers (Schoelynck

412 et al. 2012) that support several ecosystem functions in the river (Boerema et al. 2014; Carpenter

413 and Lodge (1986); O'Hare et al. (2018); Sand-Jensen et al. (1989). A sudden loss of vegetation

414 may induce sediment erosion, which can be intensified by the burrowing activities of the crabs and

415 which may further inhibit vegetation recovery in the long term.

416

417 Isotope analyses showed that only a minority of the plant biomass is actually assimilated and that

418 leaf litter was the main food source for the crabs. This corroborates the findings of Czerniejewski

419 et al. (2010) and Roswarne et al. (2016) who showed that macrophytes contribute approximately

$42010-16 \%$ of the crabs' diet, respectively (based on gut-content analyses), and with a mesocosm

421 experiment by Rudnick et al. (2005) showing that the main food source for crabs are tree leaves.

422 The crabs' cutting behaviour, and not consumption, was found to be the main cause of macrophyte

423 shoot removal, which corroborates previous studies on the destructive effects of (invasive) crayfish

424 and crabs (e.g. Jin et al. 2003; Lodge et al. 1994, van der Wal et al. 2013). Crab pinch strength

425 proved to be an order of magnitude higher than what is needed to cut the plant stems. Though

426 video recording did not observe crabs pinching through the stems and so removing macrophyte

427 fragments, crab movement through the vegetation and crab-crab interactions resulted in breaks and

428 snaps in macrophyte shoot tissue (Fig. 6). Therefore, we put forward the hypothesis that crabs

429 mostly do not pinch the shoots at full force, but rather just grasp them. Yet such action may be

430 enough to damage plant cells (trauma), causing the shoot to die locally (necrosis), which results in

431 plant fragments being repelled after which they start floating. The process of necrosis takes some

432 time, which may also explain the time lag between the introduction of the crabs and observation

433 of the first floating shoots. Variation in total macrophyte biomass was found among setups with 
434 different crab densities under the same treatment. This variation can only be explained by a reduced

435 plant growth in tanks where were present, because similar initial biomass was planted, abiotic

436 circumstances were the same within the same stress treatment and crabs consumed only little

437 biomass. Growing and branching potential of the macrophytes decreases with every trauma and 438 repelled shoot. This results in a smaller shoot density, in lower biomass production and a higher 439 risk for further crab damage.

441 The additional influence of abiotic stress had a significant effect on how fast vegetation will 442 decline. In the presence of chemical stress, the start of vegetation loss appeared sooner in time and 443 led to more severe losses after 25 days even at the lowest crab density, compared to the control 444 treatment. Macrophytes exposed to chemical contaminants such as EDTA, glyphosate and its 445 metabolite aminomethylphosphonic acid (AMPA) are expected to experience stress or injury 446 which could accelerate necrosis in the shoots that were damaged by the crabs (Reddy et al. 2004).

447 Note that the concentrations used in the experiment were at the upper end of what can be found in

448 rivers in, for example, the Nete catchment but are realistic near the mixing zone of effluent 449 discharge or during periods of drought and a reduced dilution effect of contaminants. Also note 450 that we have used Roundup® to add glyphosate, but we did not analyse the adjuvants in the 451 herbicide, which can also be stressful, nor are any interaction or additive toxicological effects 452 between EDTA and glyphosate considered. Plants under the reduced light treatment reacted 453 ambiguously. At the lowest crab density, plants were cut loose much sooner than in the control 454 treatment, while this was much later at the two highest crab densities. The higher nutrient content 455 (i.e. higher $\mathrm{N}$ and $\mathrm{P}$ content and lower $\mathrm{C}: \mathrm{N}$ and $\mathrm{C}: \mathrm{P}$ ratios) of plants grown under the light treatment 456 would indicate that they are more nutritious and more likely to be consumed, if other factors 
457 regarding plant palatability such as structural defences or secondary compounds are constant 458 between the treatments (Elser et al. 2000, Gross and Bakker 2012). Additionally, the lower shear 459 strength of these plants would make them easier to cut and more vulnerable to crab pinches than

460 in the other treatments. However, this effect was only clear in case of 0.3 ind. $\mathrm{m}^{-2}$ crab density 461 (notably where crab-crab interactions are not present). Additionally, we hypothesize that lower 462 light intensity may have itself had an ambiguous effect on the crabs' behaviour, as it mainly is a 463 nocturnal animal (Gilbey et al. 2008). Darker conditions might decrease the time that crabs hide

464 in the vegetation resulting in a lower plant trauma prevalence during crab-crab interactions, but it 465 might also have increased crab mobility which may result in higher plant trauma prevalence. 466 Specific behaviour experiments are needed to sort this out.

468 The impact of the Chinese mitten crab on aquatic ecosystems in Europe remains largely unknown. 469 However, our study suggests that the crab can potentially have a high impact on macrophyte 470 communities if crab densities are large compared to the standing macrophyte biomass. Actual 471 density data are not often published which is a shortcoming to estimate the risk for aquatic 472 vegetation. Yet absolute values of crab numbers caught show an increase across Europe in the last 473 decades, e.g. Baltic Sea region (Ojaveer et al. 2007), Spain (Garcia-de-Lomas et al. 2010), Poland 474 (Normant et al. 2000; Wójcik-Fudalewska and Normant-Saremba 2016), France, Belgium, The 475 Netherlands, Germany and UK (Herborg et al. 2003, 2005). Ecological niche modelling 476 demonstrated that most of Europe is vulnerable to invasion by Chinese mitten crabs and especially 477 rivers flowing into the Mediterranean Sea appear to be a highly suitable habitat (Herborg et al. 478 2007). With climate change, river water temperatures are projected to increase on average by $0.8-$ $4791.6{ }^{\circ} \mathrm{C}$ by 2100 (some European river systems such as the Rhine, Danube and Rhone even up to 
481 the same time, abiotic stress to macrophytes caused by climate change is also likely to increase in

482 the near future (Short et al. 2016; Reitsema et al. 2018), which can make plants more vulnerable

483 to crabs (Hidding et al. 2016). Many rivers may become devoid of macrophytes, which is currently

484 the case for parts of the Grote Nete river in Belgium (VMM 2017). This may result in negative

485 consequences for the aquatic system as a whole and makes it hard to reach the Water Framework

486 Directive goals aiming at good water quality by 2027 .

\section{References}

Ang KY, Lucas PW, Tan HTW (2008) Novel way of measuring the fracture toughness of leaves and other thin films using a single inclined razor blade. New Phytol 177: 830-837.

Barko JW, Smart RM (1981) Comparative influences of light and temperature on the growth and metabolism of selected submersed freshwater macrophytes. Ecol Monogr 51(2): 219-235. Belgium. Ecosyst Serv 7: 46-56.

Bouma S, Soes DM (2010) A risk analysis of the Chinese mitten crab in The Netherlands. Eindrapportage Bureau Waardenburg, Culemborg, The Netherlands. 52pp.

502 Carpenter SR, Lodge DM (1986) Effects of submerged macrophytes on ecosystem processes. 503 Aquatic Botany 26:341-370.

Czerniejewski P, Rybczyk A, Wawrzyniaki W (2010) Diet of the Chinese mitten crab, Eriocheir sinensis $\mathrm{H}$. Milne Edwards, 1853, and potential effects of the crab on the aquatic community in the River Odra/Oder estuary (N.-W. Poland). Crustaceana 83(2): 195-205. 
512 Elser JJ, Fagan WF, Denno RF, Dobberfuhl DR, Folarin A, Huberty A, Interlandi S, Kilham SS, 513 McCauley E, Schulz KL, Siemann EH, Sterner RW (2000) Nutritional constraints in terrestrial 514 and freshwater food webs. Nature 408(6812): 578-580.

EU Regulation No 1143/2014 of the European Parliament and of the Council of 22 October 2014 on the prevention and management of the introduction and spread of invasive alien species. OJ L $317,4.11 .2014$, p. $35-55$

European Environmental Agency (2012). The impacts of invasive alien species in Europe. Technical report No 16/2012. 114 pp. doi:10.2800/65864

Garcia-de-Lomas J, Dana E.D., López-Santiago J, González R, Ceballos G, Ortega F (2010) Management of the Chinese mitten crab, Eriocheir sinensis (H. Milne Edwards, 1853) in the Guadalquivir Estuary (Southern Spain). Aquat Invasions 5(3): 323-330.

\section{Gilbey V, Attrill MJ, Coleman RA (2008) Juvenile Chinese mitten crabs (Eriocheir sinensis)}

in the Thames estuary: distribution, movement and possible interactions with the native crab Carcinus maenas. Biol Invasions 10:67-77.

Gross EM, Bakker ES (2012) The role of plant secondary metabolites in freshwater macrophyteherbivore interactions: limited or unexplored chemical defences? In Iason GR, Dicke M, Hartley SE (eds). The ecology of plant secondary metabolites: from genes to global processes. Cambridge University Press, British Ecological Society, Cambridge, 154-169.

Hangarter RP, Stasinopoulos TC (1991) Effect of Fe-catalyzed photo oxidation of EDTA on root growth in plant culture media. Plant Physiol 96: 843-847.

Herborg L-M, Rushton SP, Clare AS, Bentley MG (2003) Spread of the Chinese mitten crab (Eriocheir sinensis, H. Milne Edwards) in continental Europe. Hydrobiologia 503: 21-28.

Herborg L-M, Rushton SP, Clare AS, Bentley MG (2005) The invasion of the Chinese mitten crab (Eriocheir sinensis) in the United Kingdom and its comparison to continental Europe. Biol Invasions 7: 959-968.

Herborg L-M, Rudnick DA, Siliang Y, Lodge DM, MacIsaac HJ (2007) Predicting the range of Chinese mitten crabs in Europe. Conserv Biol 21(5): 1316-1323.

Hidding B, Bakker ES, Hootsmans MJM, Hilt S (2016) Synergy between shading and herbivory triggers macrophyte loss and regime shifts in aquatic systems. Oikos 125: 1489-1495. 
Jacob U, Mintenbeck K, Brey T, Knust R, Beyer K (2005) Stable isotope food web studies: a case for standardized sample treatment. Mar Ecol Prog Ser 287:251-253.

Jin G, Xie P, Li ZJ, Kuwabara R (2001) Food habits and feeding rhythm of the early juvenile Chinese mitten crab (Eriocheir sinensis) in experimental tanks. J Freshwater Ecol, 16(4), 647-648.

Jin G, Xie P, Li ZJ (2003) Food habits of two-year-old Chinese mitten crab (Eriocheir sinensis) stocked in Lake Bao'an. China. J Freshwater Ecol 18(3), 369-375.

Jin G, Xie P, Li Z (2001) Effects of the stocking density and body size of the mitten Crab (Eriocheir sinensis) on aquatic plant biomass. J Freshwater Ecol 16(3): 341-345.

Kristensen DK, Kristensen E, Mangion P (2010) Food partitioning of leaf-eating mangrove crabs (Sesarminae): Experimental and stable isotope $\left({ }^{13} \mathrm{C}\right.$ and $\left.{ }^{15} \mathrm{~N}\right)$ evidence. Estuar Coast Shelf S 87: 583-590.

Lodge DM, Kershner MW, Aloi JE, Covich AP (1994) Effects of an omnivorous crayfish (Orconectes rusticus) on a freshwater littoral food web. Ecology 75(5):1265-1281.

Lorrain A, Paulet YM, Chauvaud L, Savoye N, Donval A, Saout C (2002) Differential delta C-13 and delta N-15 signatures among scallop tissues: implications for ecology and physiology. J Exp Mar Biol Ecol 275:47-61.

Mao Z, Gu X, Zeng Q (2016) Food sources and trophic relationships of three decapod crustaceans: insights from gut contents and stable isotope analyses. Aquac Res 47, 2888-2898.

McCutchan JH, Lewis WM, Kendall C, McGrath CC (2003) Variation in trophic shift for stable isotope ratios of carbon, nitrogen, and sulfur. Oikos 102:378-390.

Normant M, Wiszniewska A, Szaniawska A (2000) The Chinese mitten crab Eriocheir sinensis (Decapoda: Grapsidae) from Polish waters. Oceanologia 42(3): 375-383.

O'Hare MT, Aguiar FC, Asaeda T, Bakker ES, Chambers PA, Clayton JS, Elger A, Ferreira TM, Gross EM, Gunn IDM, Gurnell AM, Hellsten S, Hofstra DE, Li W, Mohr S, Puijalon S, Szoszkiewicz K, Willby NJ, Wood KA (2018) Plants in aquatic ecosystems: current trends and future directions. Hydrobiologia 812:1-11. 9:409-418. 
Parnell A, Jackson A (2013) Stable Isotope Analysis in R. vol 4.2. R Foundation for statistical computing: Vienna.

Parnell AC, Inger R, Bearhop S, Jackson AL (2010) Source partitioning using stable isotopes: coping with too much variation. Plos One 5(3): e9672.

Phillips DL, Koch PL (2002) Incorporating concentration dependence in stable isotope mixing models. Oecologia 130:114-125.

R Development Core Team (2016). R: a Language and Environment for Statistical Computing. vol 3.3.2. R Foundation for Statistical Computing: Vienna.

Reddy KN, Rimando AM, Duke SO (2004) Aminomethylphosphonic Acid, a Metabolite of Glyphosate, Causes Injury in Glyphosate-Treated, Glyphosate-Resistant Soybean. J Agr Food

Reitsema RE, Meire P, Schoelynck J (2018). The future of freshwater macrophytes in a changing world: dissolved organic carbon quantity and quality and its interactions with macrophytes. Front Plant Sci. 9:629.

Rogers L (2000) The feeding ecology of the invasive Chinese mitten crab, Eriocheir sinensis: implications for California's freshwater communities. Senior Research Seminar, Environmental Science Group Major. University of California at Berkeley, Berkeley, CA.

Rosewarne PJ, Mortimer RJG, Newton RJ, Grocock C, Wing CD, Dunn AM (2016) Feeding behaviour, predatory functional responses and trophic interactions of the invasive Chinese mitten crab (Eriocheir sinensis) and signal crayfish (Pacifastacus leniusculus). Freshwater Biol 61: 426443.

Rudnick DA, Hieb K, Grimmer KF, Resh VH (2003) Patterns and processes of biological invasion: The Chinese mitten crab in San Francisco Bay. Basic Appl Ecol 4(3): 249-262.

Rudnick DA, Chan V, Resh VH (2005) Morphology and impacts of the burrows of the Chinese mitten crab, Eriocheir sinensis, in South San Francisco Bay, California, U.S.A. Crustaceana 78(7): 787-807. 
Schoelynck J, De Groote T, Bal K, Vandenbruwaene W, Meire P, Temmerman S (2012) Selforganised patchiness and scale-dependend biogeomorphic feedbacks in aquatic river vegetation. Ecography 35(8): 760-768.

Short FT, Kosten S, Morgan PA, Malone S, Moore GE (2016) Impacts of climate change on submerged and emergent wetland plants. Aquat Bot 135: 3-17.

Thongtham N, Kristensen E (2005) Carbon and nitrogen balance of leaf-eating sesarmid crabs (Neoepisesarma versicolor) offered different food sources. Estuar Coas Shelf S 65: 213e222. B, Bakker ES (2013). Invasive crayfish threaten the development of submerged macrophytes in lake restoration. PLoS One 2013; 8(10): e78579. (2013) Global river discharge and water temperature under climate change. Global Environ Chang 23(2): 450-464.

VMM Vlaamse Milieu Maatschappij 2015. Macrofyten in de Grote Nete. Eerste tussentijds rapport. D/2015/6871/051. 39pp. (In Dutch)

VMM Vlaamse Milieu Maatschappij 2017. Macrofyten in de Grote Nete. Tweede tussentijds rapport. D/2017/6871/042. 45pp. (In Dutch)

Eindrapportage Bureau Waardenburg, Culemborg, The Netherlands. 52pp

Walinga I, Van Vark W, Houba VJG, Van Der Lee JJ (1989) Plant analysis procedures. Soil and Plant Analysis, Part 7, Wageningen, NL.

Wang H, Xu C, Wang H, Kosten S (2017) Long-term density dependent effects of the Chinese mitten crab (Eriocheir sinensis (H. Milne Edwards, 1854)) on submersed macrophytes. Aquat Bot 140: 84-91. sinensis on blue mussel Mytilus edulis trossulus - Laboratory studies of claw strength, handling behavior, consumption rate, and size selective predation. Oceanologia, 57(3) 263-270. 
670 Wójcik-Fudalewska D, Normant-Saremba M (2016) Long-term studies on sex and size structures 671 of the non-native crab Eriocheir sinensis from Polish coastal waters. Mar Biol Res 12(4): 412672418.

673

674 Zefferman EP (2004) Increasing canopy shading reduces growth but not establishment of Elodea 675 nuttallii and Myriophyllum spicatum in stream channels. Hydrobiologia 734(1): 159-170. 676 


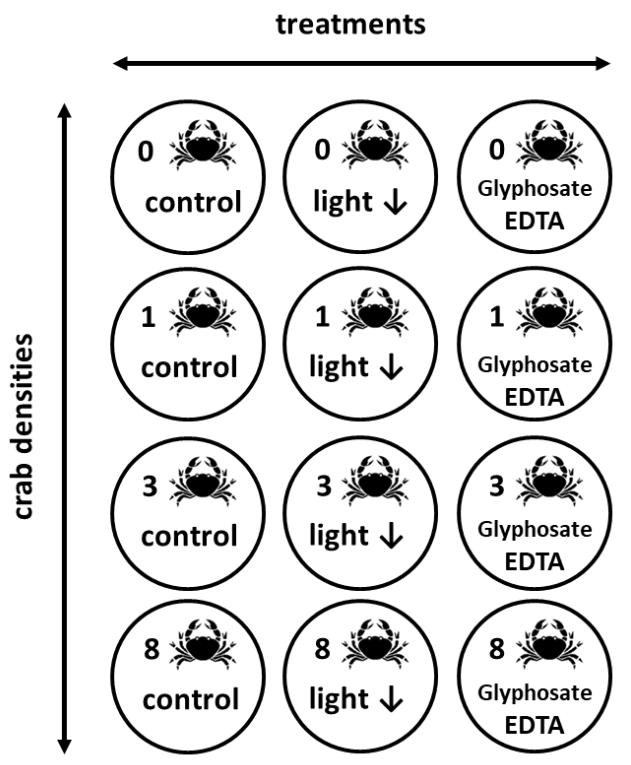

Fig. 1 Experimental setup. Twelve mesocosm tanks were installed combining 4 crab densities with 3 treatments. 


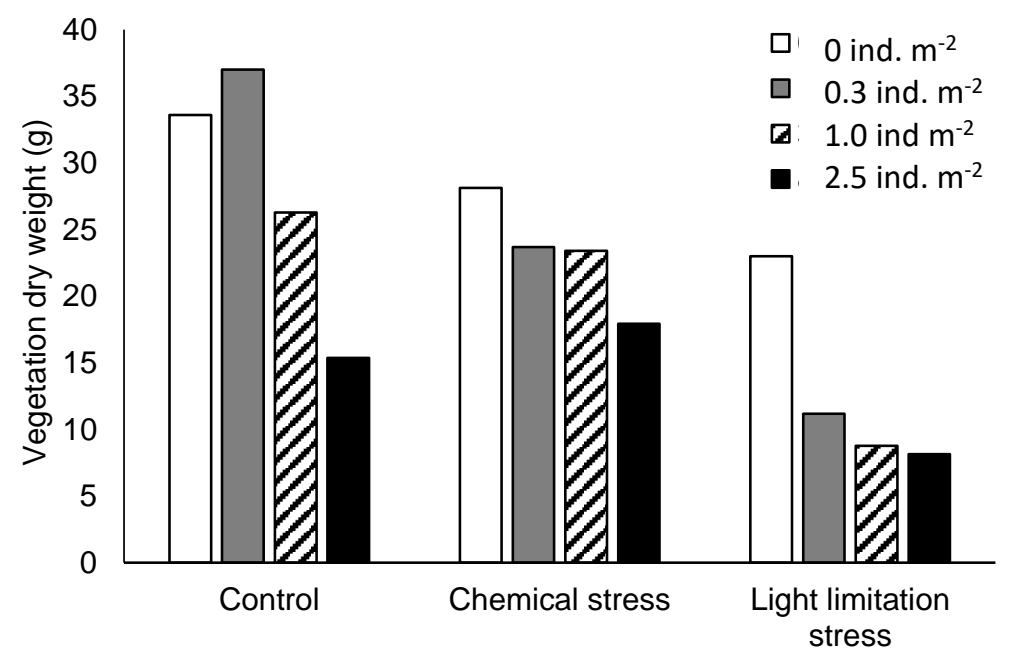

Fig. 2 Total plant biomass in each of the treatments and per crab density.

Total plant biomass is the sum of the floating plant biomass collected during the experiment and the remaining plant biomass at the end of the experiment. 


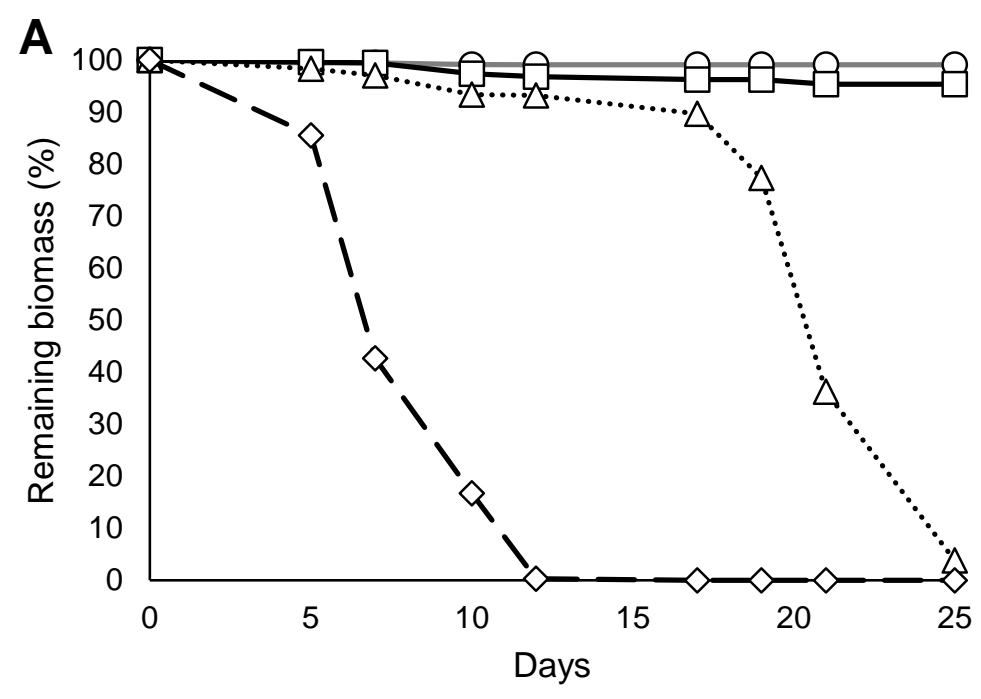

681

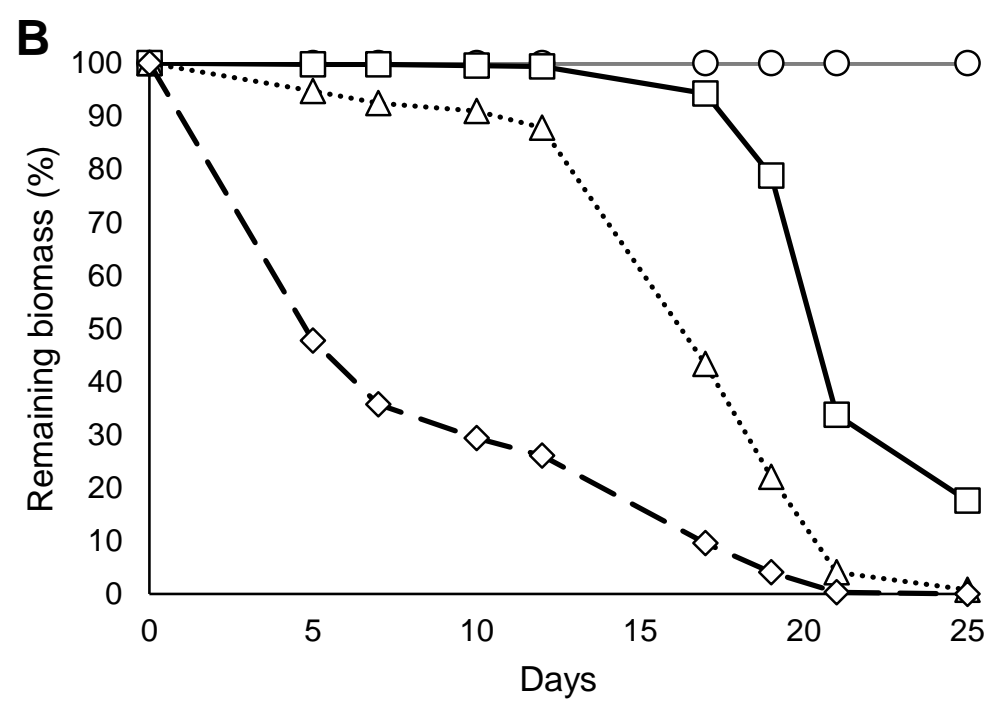

682

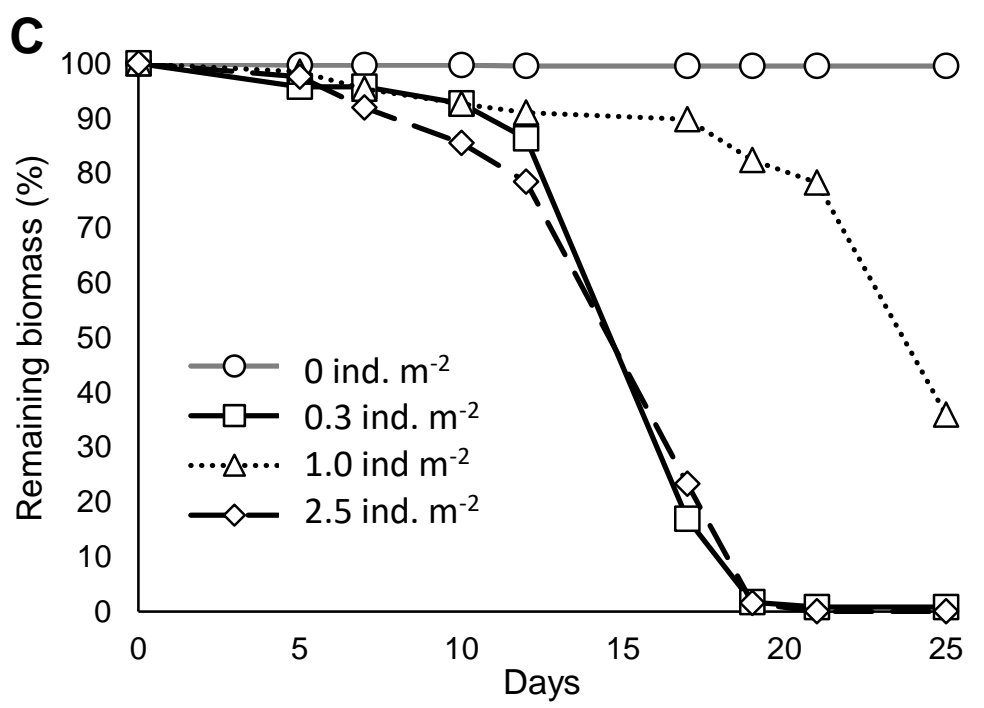

Fig. 3 Reduction of plant biomass in the control (A), chemical stress (B) and light reduction stress (C) ponds with different crab densities. 

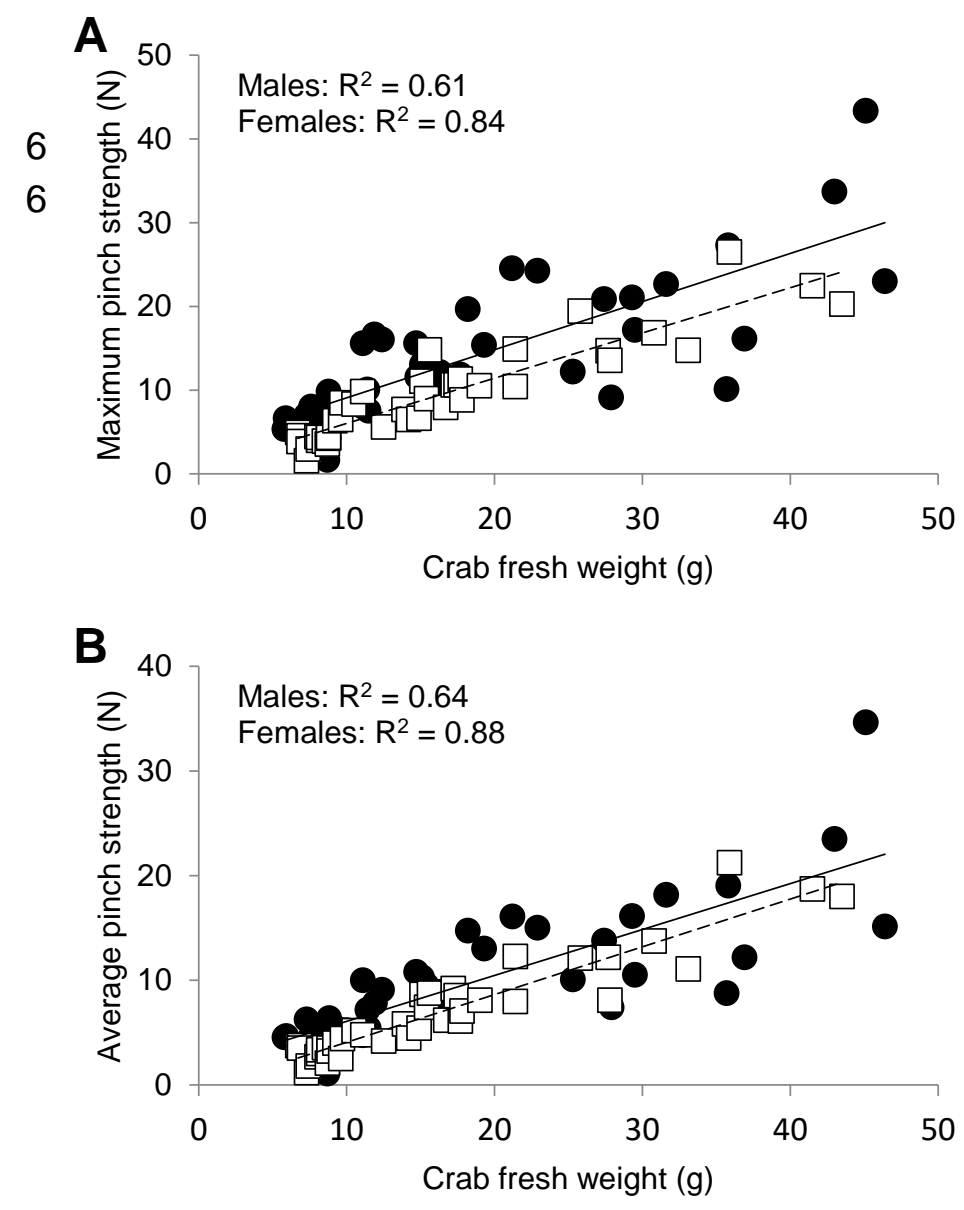

Fig. 4 Relationship between maximum (A) and average (B) crab pinch strength and crab fresh weight $(\mathrm{g})$. Circles and solid trendlines represent male crabs $(n=40)$, while squares and dashed trendlines represent female crabs $(n=40)$. All relationships were significant at the $p<0.01$ level. 


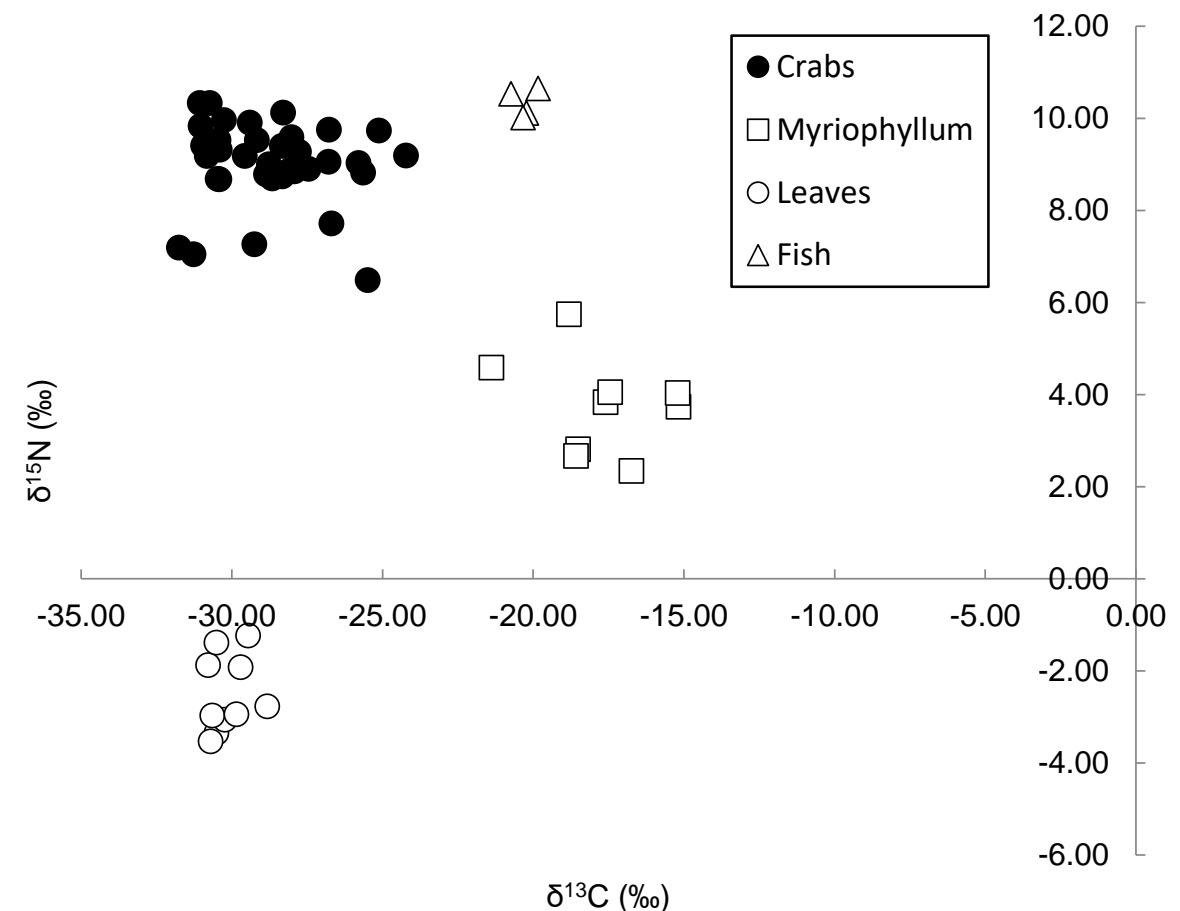$$
\delta^{13} \mathrm{C}(\%)
$$

Fig. 5 Stable isotope signatures of $\delta^{13} \mathrm{C}$ and $\delta^{15} \mathrm{~N}$ of the Chinese mitten crabs and their possible food sources $M$. spicatum, terrestrial leaves and supplemented fish meat. 


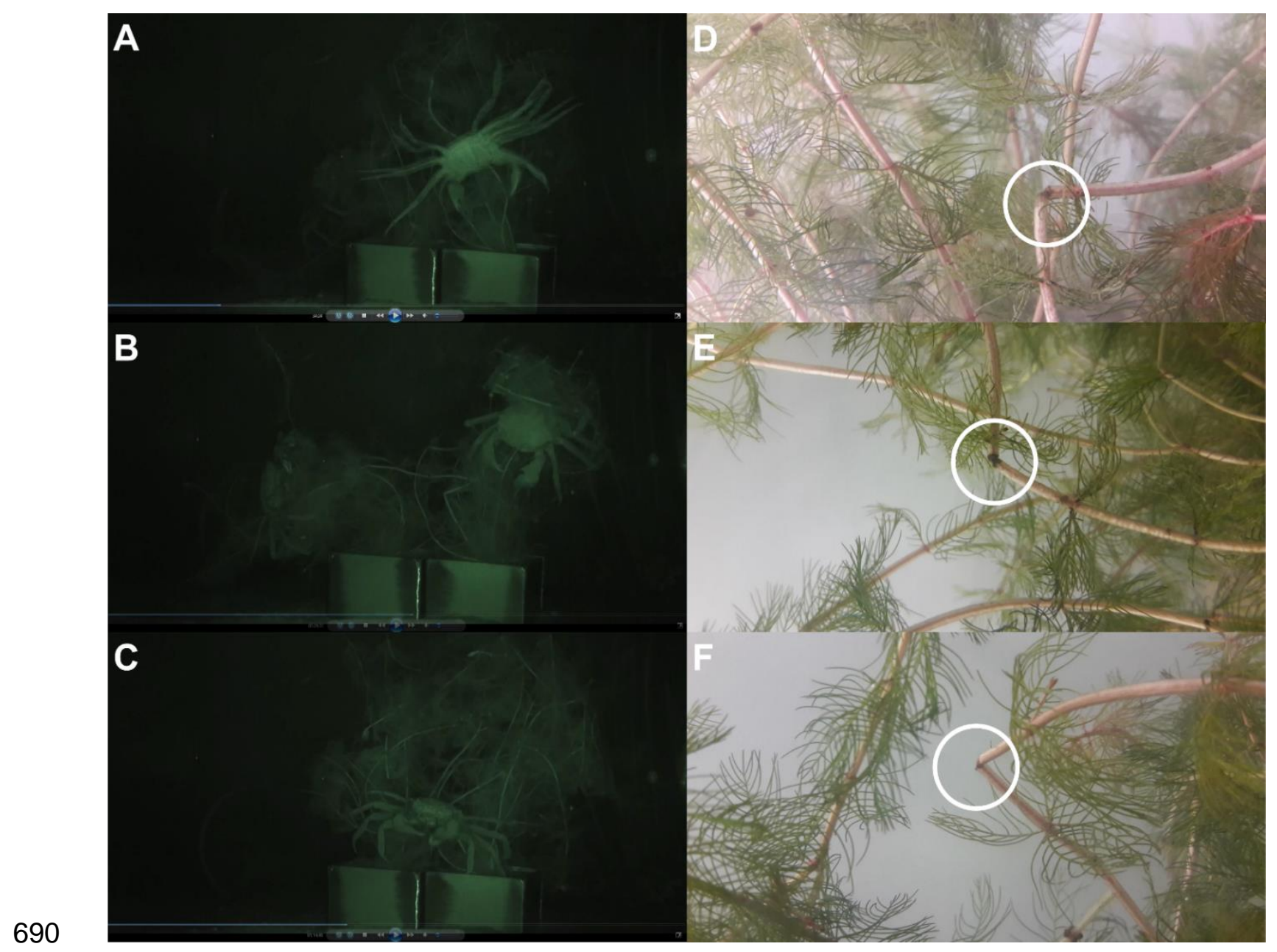

Fig. 6 Images of video recording (A-C) and pictures (D-F) of the interaction of 2 Chinese Mitten Crab with a macrophyte patch. (A) A crab grasping the macrophyte with front chelae. (B) The crabs disturbing the macrophyte by clambering on top of it and substantially bending its stems. (C) A crab presumably eating the macrophyte. This goes on for a few minutes in this instance. (D - F) Breaks and snaps (trauma) in some of the macrophytes stems due to crab activities. 
Table 1 Abiotic conditions of the tanks per month and per treatment (control, chemical stress and light limitation stress). Data are mean values \pm standard deviation $(\mathrm{n}=4)$ for $\mathrm{PO}_{4}{ }^{3-}$, total dissolved nitrogen (TDIN), $\mathrm{pH}$, electric conductivity (EC) and $\mathrm{O}_{2}$. Temperature was logged continuously and averaged for the whole month period ( \pm standard deviation). Irradiance was logged continuously and the median of all day-time values was calculated for the whole month period

\begin{tabular}{|l|l|l|l|l|l|l|l|l|}
\hline & $\mathbf{P O}_{4}{ }^{\mathbf{}}$ & TDIN & $\mathbf{p H}$ & $\mathbf{E C}$ & $\mathbf{O}_{\mathbf{2}}$ & $\mathbf{O}_{\mathbf{2}}$ & $\mathbf{T e m p}$ & Irradiance \\
\hline Control & $\left(\mathbf{m g ~ P ~ L}^{-1}\right)$ & $\left(\mathbf{m g ~ N ~ L}^{-1}\right)$ & $(-)$ & $\left(\boldsymbol{\mu S ~ \mathbf { ~ m } ^ { - 1 } )}\right.$ & $(\mathbf{\%})$ & $\left(\mathbf{m g ~ L}^{-1}\right)$ & $\left({ }^{\circ} \mathbf{C}\right)$ & $\left(\mathbf{W ~ m}^{-2}\right)$ \\
\hline April & $0.02 \pm 0.00$ & $3.7 \pm 0.0$ & $8.6 \pm 0.0$ & - & $106 \pm 1$ & $10.3 \pm 0.1$ & $15.0 \pm 1.0$ & 163 \\
\hline May & $<0.02$ & $2.6 \pm 0.1$ & $8.9 \pm 0.1$ & $712 \pm 27$ & $126 \pm 5$ & $10.4 \pm 0.3$ & $23.3 \pm 1.0$ & 157 \\
\hline June & $<0.02$ & $0.2 \pm 0.0$ & $9.0 \pm 0.3$ & $664 \pm 38$ & - & - & $22.4 \pm 1.0$ & 230 \\
\hline Chemical & & & & & & & & \\
\hline April & $0.02 \pm 0.00$ & $3.7 \pm 0.0$ & $8.6 \pm 0.0$ & - & $106 \pm 0$ & $10.3 \pm 0.1$ & $15.0 \pm 1.0$ & 163 \\
\hline May & $<0.02$ & $2.1 \pm 0.1$ & $9.0 \pm 0.1$ & $712 \pm 27$ & $131 \pm 4$ & $10.8 \pm 0.3$ & $22.8 \pm 1.0$ & 157 \\
\hline June & $<0.02$ & $0.0 \pm 0.0$ & $8.3 \pm 0.3$ & $714 \pm 24$ & - & - & $21.6 \pm 1.0$ & 230 \\
\hline Light & & & & & & & & \\
\hline April & $0.02 \pm 0.00$ & $3.7 \pm 0.0$ & $8.6 \pm 0.0$ & - & $108 \pm 1$ & $10.4 \pm 0.1$ & $15.5 \pm 1.0$ & 164 \\
\hline May & $<0.02$ & $2.7 \pm 0.1$ & $8.6 \pm 0.0$ & $752 \pm 40$ & $114 \pm 1$ & $9.4 \pm 0.1$ & $21.9 \pm 1.0$ & 56 \\
\hline June & $<0.02$ & $1.2 \pm 0.2$ & $8.4 \pm 0.2$ & $720 \pm 37$ & - & - & $20.9 \pm 1.0$ & 59 \\
\hline
\end{tabular}


699 Table 2 Potential contributions of the different possible food sources to the crabs' diets. Ranges represent $90 \%$ credible intervals (5-95 percentile ranges) with median contribution in parentheses, 701 calculated using the SIAR mixing model. The analysis of the single crab in the control treatment 702 had analytical errors and no data could be generated.

\begin{tabular}{|l|l|l|l|l|}
\hline Treatment & $\begin{array}{l}\text { Crab densities } \\
\left(\mathbf{i n d} . \mathbf{~ m}^{-2}\right)\end{array}$ & M. spicatum & Tree leaves & Fish \\
\hline Control & 0.3 & - & - & - \\
\hline Control & 1.0 & $0-0.45(0.13)$ & $0.35-0.81(0.66)$ & $0.13-0.29(0.21)$ \\
\hline Control & 2.5 & $0-0.29(0.05)$ & $0.50-0.81(0.73)$ & $0.17-0.26(0.21)$ \\
\hline Light limitation & 0.3 & $0-0.62(0.27)$ & $0.14-0.86(0.52)$ & $0.01-0.48(0.16)$ \\
\hline Light limitation & 1.0 & $0-0.62(0.31)$ & $0.10-0.78(0.45)$ & $0.06-0.49(0.22)$ \\
\hline Light limitation & 2.5 & $0-0.22(0.05)$ & $0.57-0.80(0.73)$ & $0.18-0.25(0.22)$ \\
\hline Chemical & 0.3 & $0-0.64(0.32)$ & $0.06-0.78(0.44)$ & $0.01-0.54(0.21)$ \\
\hline Chemical & 1.0 & $0-0.47(0.16)$ & $0.31-0.72(0.63)$ & $0.08-0.37(0.19)$ \\
\hline Chemical & 2.5 & $0-0.29(0.06)$ & $0.53-0.86(0.75)$ & $0.13-0.24(0.18)$ \\
\hline
\end{tabular}


705 Table 3 Regrowth of plant biomass after (a)biotic stresses were relieved. Data are plant dry mass 706 (g DM) after a short and long term period. The symbol * indicate the presence of flowers at the 707 time of evaluation.

708

\begin{tabular}{|l|l|l|l|}
\hline Treatment & $\begin{array}{l}\text { Crab densities } \\
\left(\text { ind. } \mathbf{~ m}^{-2}\right)\end{array}$ & $\begin{array}{l}\text { Regrowth after 47 } \\
\text { days (g DM) }\end{array}$ & $\begin{array}{l}\text { Regrowth after 345 } \\
\text { days (g DM) }\end{array}$ \\
\hline Control & 0 & $6.9^{*}$ & $21.5^{*}$ \\
\hline Control & 0.3 & 0 & $2.3^{*}$ \\
\hline Control & 1.0 & 0 & 0.2 \\
\hline Control & 2.5 & 0 & $0.4^{*}$ \\
\hline Light limitation & 0 & $3.2^{*}$ & $14.6^{*}$ \\
\hline Light limitation & 0.3 & 0 & 0.1 \\
\hline Light limitation & 1.0 & 0 & 0.6 \\
\hline Light limitation & 2.5 & 0 & 0 \\
\hline Chemical & 0 & $6.7^{*}$ & $22.0^{*}$ \\
\hline Chemical & 0.3 & 0 & $1.0^{*}$ \\
\hline Chemical & 1.0 & 0 & 0.2 \\
\hline Chemical & 2.5 & 0.1 & $4.2^{*}$ \\
\hline
\end{tabular}

